\title{
Shunt assistant device deception due to pseudovertical posturing
}

\author{
Claudia Craven", Neekhil A Patel, Hasan Asif, Aswin Chari, Edward W Dyson, Samir A Matloob, Patricia Haylock-Vize \\ , Simon D Thompson, Syed N Shah, Andrew R Stevens, Tarek Mostafa, Huan Wee Chan, Jinendra Ekanayake, \\ Ahmed K Toma, Laurence D Watkins
}

From Hydrocephalus 2015

Banff, Canada. 18-21 September 2015

\section{Introduction}

The ever present need to balance over drainage with under drainage in hydrocephalus has required innovations including adjustable valves with antigravity devices. These are activated in the vertical position to prevent siphoning. We describe a group of patients who presented with unexplained under drainage caused by activation of antigravity shunt components produced by peculiar head/body position.

\section{Methods}

Single centre case series of hydrocephalus patients, treated with ventriculo-peritoneal shunt insertion. These patients presented with clinical and radiological under drainge syndrome. Medical notes were reviewed for clinical picture and outcome. Radiological studies were reviewed assessing shunt placement and ventricular size.

\section{Results}

Four patients presented with clinical and radiological under drainage syndrome. A consistent posturing of long term hyper-flexion of the neck whilst lying supine was observed. All patients had similar shunt construct (adjustable Miethke proGAV valve and shunt assistant antigravity component). In each of those patients a hypothesis was formulated that neck flexion was activating the shunt assistance antigravity component in supine position. All patients underwent shunt revision surgery removing the shunt assistant device from the cranium and adding an antigravity component to the shunt system at the chest. All patients had clinical and radiological improvement.

\footnotetext{
* Correspondence: claudia.craven@gmail.com

* Correspondence: claudia.craven@gmail.com \& Neurosurgery, Queen Square, London, UK
}

\section{Conclusions}

The combination of raised ICP when supine and a resistant shunt assistant could be blamed for worsening hydrocephalus. In bedridden hydrocephalus patients with a shunt assistant, consider the possibility of shunt deception due to abnormal neck positioning. In these patients, antigravity devices should be placed at the chest.

Published: 18 September 2015

doi:10.1186/2045-8118-12-S1-P10

Cite this article as: Craven et al: Shunt assistant device deception due to pseudovertical posturing. Fluids and Barriers of the CNS 2015 12(Suppl 1):P10.
Submit your next manuscript to BioMed Central and take full advantage of:

- Convenient online submission

- Thorough peer review

- No space constraints or color figure charges

- Immediate publication on acceptance

- Inclusion in PubMed, CAS, Scopus and Google Scholar

- Research which is freely available for redistribution

Submit your manuscript at www.biomedcentral.com/submit
() Biomed Central 